\title{
KOMIK STRIP TENTANG CARA MENJAGA KESEHATAN MATA DI MASA PEMBELAJARAN DARING BAGI PELAJAR USIA 9-16 TAHUN
}

\author{
Arjuna Bangsawan ${ }^{1}$ \\ Restu Hendriyani ${ }^{2}$ \\ Brigitte Theanita Halim ${ }^{3}$ \\ Institut Informatika Indonesia, Surabaya \\ arjuna@ikado.ac.id
}

\begin{abstract}
Abstrak
Pandemi COVID-19 mengharuskan pelajar untuk melakukan pembelajaran secara daring. Selain untuk sekolah daring, pelajar banyak menghabiskan waktunya menggunakan gadget untuk keperluan lain. Penggunaan gadget yang terlalu berlebihan dapat menyebabkan masalah penglihatan pada pelajar berusia 9-16 tahun yang sedang dalam masa pubertas. Perancangan ini menggunakan metode penelitian kualitatif dengan melakukan wawancara dan observasi. Tahapan pembuatan perancangan ini adalah mempersiapkan konsep berdasarkan penelitian dan melakukan proses pembuatan karya seperti sketsa, outlining, coloring dan editing. Perancangan ini menghasilkan komik strip mengenai cara menjaga Kesehatan mata di masa pembelajaran daring bagi pelajar usia 9-16 tahun berjudul "Cerita Mata Kita" yang dipublikasikan dalam akun Instagram @komik_ceritamatakita.
\end{abstract}

Kata kunci: Komik Strip, Instagram, Kesehatan Mata, Pembelajaran Daring,

\begin{abstract}
This COVID-19 pandemic causes students to do online learning. Besides online schools, students also spend their time using gadgets for other purposes. This excessive use of technology may cause eye health problems for students between 9-16 years old who are still in the growing phase. This project uses qualitative research methods, such as doing interviews and observing. Steps in designing this project are preparing some concepts based on the research and then creating the project by making sketches, outlining, coloring and editing. This project will produce a series of comic strips about taking care of the eye's health of students between 9-16 years old during online school called "Cerita Mata Kita" and published on an Instagramaccount @komik_ceritamatakita.
\end{abstract}

Key words: Comic Strips, Instagram, Eye Health, Online School, Students Between 9 Old 


\section{PENDAHULUAN}

Pandemi COVID-19 di tahun 2020 ini mengharuskan pelajar melakukan pembelajaran dari rumah secara daring. Pembelajaran daring ini sangat membatasi ruang gerak pelajar, karena mengharuskan menatap layer gadget dalam waktu yang lama. Intensitas penggunaan gadget yang berlebihan di masa pembelajaran daring ini menyebabkan timbulnya masalah pengelihatan pada pelajar yang sedang dalam masa pubertas, terutama pada pelajar dengan faktor genetika miopia dari orangtuanya. Masalah penglihatan ini dapat dikurangi dan bahkan dicegah dengan memberikan informasi dan edukasi yang tepat, salah satunya adalah melalui media sosial seperti Instagram. Komik strip adalah konten Instagram berbentuk komik singkat yang mampu memberikan informasi secara singkat, padat dan mudah dimengerti sekaligus menghibur.

Untuk itu, penulis merancang media komik strip mengenai cara menjaga kesehatan mata selama pembelajaran daring. Tujuan dari perancangan ini adalah untuk mengedukasi pelajar usia 9-16 tahun mengenai cara menjaga kesehatan mata di masa pembelajaran daring.

\section{KAJIAN TEORI}

\section{Pengertian Astenopia}

Astenopia berasal dari kata " $a$ " yang berarti tidak, "sthenos" berarti kekuatan dan "ops" berarti penglihatan. Astenopia adalah kondisi dimana kekuatan penglihatan semakin melemah yang diakibatkan oleh penggunaan kedua bola mata untuk aktivitas jarak dekat secara intens dan berlebihan. Astenopia bukanlah penyakit mata, namun merupakan kumpulan gejala ketidaknyamanan mata dan sangat umum terjadi pada siapa saja dalam semua usia. Penelitian oleh Vilela et al di Brazil Selatan pada 964 anak berusia 6-16 tahun ditemukan kondisi prevalensi astenopia sebesar $24,7 \%$ dan $50 \%$ diantaranya menderita insufisiensi akomodasi. Di Indonesia sendiri ditemukan angka kejadian prevalensi astenopia yang cukup tinggi, yaitu 69,7\% (Amanda \& Fernanda, 2018, p.2-3).

Kebiasaan dan gaya hidup yang kurang tepat dapat mengakibatkan terjadinya astenopia. Astenopia akibat penggunaan gadget berlebihan disebut juga computer vision syndrome (CVS). 


\section{Pengertian Miopia}

Miopia adalah kondisi abnormal penglihatan dimana panjang aksial mata lebih panjang karena ruang vitreal yang memanjang. Kondisi ini umumnya dirasakan di usia dini dan berpotensi berkembang ketika beranjak remaja. Miopia dalam jangka panjang dapat menyebabkan kecacatan penglihatan permanen. Faktor genetika dan faktor lingkungan berperan penting dalam pertumbuhan miopia pada anak-anak di usia sekolah. Hal ini disebut juga school myopia. Hal-hal seperti faktor genetika, menggunakan gadget di ruang minim cahaya, penggunaan gadget dengan jarak terlalu dekat dan lain-lain dapat memicu terjadinya miopia.

Di masa pembelajaran daring saat ini, pelajar menghabiskan waktunya selama 7 jam menatap layer gadget, diikuti dengan kegiatan lain seperti kursus, bermain game, menonton youtube dan sebagainya. Durasi penggunaan gadget yang terlalu lama ini dan cahaya biru dari layer gadget disertai lingkungan kerja yang tidak mendukung adalah pemicu utama miopia di masa pembelajaran daring ini.

\section{Teori Komik}

Dalam Kamus Besar Bahasa Indonesia (2008), komik adalah sebuah cerita bergambar atau pelawak dan badut; sebuah cerita bergambar (dalam majalah, surat kabar, atau bentuk buku) yang mudah dicerna dan menghibur. Komik merupakan salah satu media komunikasi visual yang memiliki kelebihan dalam penyampaian informasi karena memadukan gambar dan tulisan yang dirangkai membentuk suatu alur cerita gambar. Teks dalam komik dibuat singkat, padat dan mudah dimengerti dan diikuti oleh pembaca.

Komik merupakan bahasa tersendiri yang untuk menguasai teknik pembuatannya membutuhkan keahlian menggabungkan kemampuan menggambar, menulis dan bercerita (story telling). Perlu memperhatikan cara untuk berkomunikasi atau menyampaikan pesan dengan jelas karena dalam pembuatan komik cerita dibawakan dalam bentuk gambar yang berurutan. Terdapat lima pilihan (choices) yang harus dipertimbangkan dalam pembuatan cerita komik, yaitu: 
1. Choice of moment, yaitu menentukan peristiwa apa yang penting untuk dimasukan ke dalam komik dan peristiwa apa yang perlu ditinggalkan. Pilihan aksi dan peristiwa yang tepat merupakan cara yang efisien untuk mengkomunikasikan sebuah cerita. Dalam pembuatan komik, rangkaian momen-momen tersebut dipisahkan dalam bentuk transisi panel.

2. Choice of frame, yaitu memilih jarak dan sudut yang tepat, seberapa jauh atau dekat, dan seberapa detail sebuah objek untuk memperlihatkan sebuah momen. Komposisi, keseimbangan, sudut pandang dan pemotongan gambar dapat mempengaruhi kesan pembaca terhadap dunia dalam cerita dan memberikan efek "ruang" dalam dunia cerita.

3. Choice of image, yaitu bagaimana untuk menciptakan visual karakter, obyek dan lingkungan. Detail yang spesifik sangat diperlukan dalam penggambaran visual komik, anatomi dan perspektif karena dapat menghasilkan makna yang berbeda.

4. Choice of word, yaitu memilih kata-kata yang tepat, menambah informasi dan cocok untuk digunakan berdampingan dengan gambar dalam panel. Ada kata-kata dapat menciptakan spesifikasi dan makna tersendiri, baik kata-kata yang jelas maupun kata-kata yang tidak bermakna (vague).

5. Choice of flow, yaitu bagaimana memandu pembaca untuk membaca komik dari awal sampai selesai dengan urutan yang benar. Umumnya, terdapat dua cara membaca panel komik, yaitu dari kiri ke kanan dan dari kanan ke kiri yang digunakan pada komik Jepang. Panel pertama akan diletakkan di atas, kemudian diikuti dengan panel berikutnya di sebelah kanan atau kiri panel pertama dan berlanjut ke bawahnya. dan hal ini juga berlaku dalam penyusunan dialog.

\section{Pengertian Komik Strip}

Umumnya, komik strip memiliki 3-6 panel dan diterbitkan secara berkala dalam surat kabar, majalah dan tabloid. Komik strip didesain untuk memungkinkan dibaca secara naratif dengan urutan kronologis. Sejak adanya media sosial, komik strip mengalami perkembangan visual yang cukup signifikan. Komik strip yang dulu hanya dibuat dengan media cetak sekarang dapat dibuat secara digital. Hal ini 
sangat memudahkan creator untuk membagikannya di media sosial. Biasanya, tema komik strip di Indonesia diangkat dari tren dan isu-isu yang sedang terjadi di masyarakat saat itu seperti kritik, pendapat pribadi maupun sekedar humor.

\section{Teori Instagram}

Instagram adalah sebuah aplikasi berbagi foto dan video yang memungkinkan pengguna mengambil foto dan video, mengaplikasikan filter digital dan membagikannya kepada sesame pengguna. Instagram juga dilengkapi oleh fitur DM (Direct Message) yang memungkinkan penggunanya untuk berkomunikasi via chatting. Instagram juga dapat digunakan untuk mencari dan berbagi informasi/ilmu pengetahuan. Di Instagram banyak akun yang membagikan informasi mengenai kesehatan, tujuan wisata, informasi yang jelas atau yang misterius, hiburan dan sebagainya. Hal ini dapat berfungsi menambah wawasan dan memperkenalkan hal baru kepada penggunanya.

\section{Perkembangan Pelajar Usia 9 - 16 Tahun}

Usia 9 - 16 tahun adalah masa awal pubertas pada remaja yang ditandai dengan perubahan fisik dan cara berpikir yang semakin dewasa. Pada usia ini, selain tubuh yang berkembang, organ mata juga ikut berkembang sehingga rentan terjadinya masalah penglihatan. Pada usia ini, mereka juga memiliki kemampuan membaca dimana mereka mampu mengambil suatu informasi dalam suatu bacaan, serta mampu mengambil kesimpulan dari informasi tersebut.

\section{METODE PENELITIAN}

Metode penelitian yang digunakan untuk perancangan ini adalah metode kualitatif, yaitu dengan mewawancarai beberapa narasumber, seperti ahli kesehatan maupun yang menjalani pembelajaran daring secara langsung.

Dari wawancara yang dilakukan dengan ahli kesehatan, diketahui bahwa pembelajaran daring dapat berdampak bagi pelajar dalam usia pertumbuhan dan sangat memungkinkan untuk menimbulkan masalah penglihatan pada pelajar seperti kelelahan mata dan miopia. Walaupun astenopia merupakan masalah penglihatan yang sangat umum, miopia merupakan masalah penglihatan yang 
cukup serius, terutama pada pelajar yang sedang dalam usia pubertas yang memiliki faktor genetika miopia dari orangtuanya.

Sedangkan dari wawancara yang dilakukan dengan pelajar di daerah Surabaya yang menjalankan system pembelajaran daring, diketahui bahwa pelajar tersebut menggunakan gadget selama rata-rata 11 jam per harinya. Beliau terkadang merasa sakit kepala, pusing dan mata kering saat terlalu lama menggunakan gadget, namun tidak dihiraukan.

Selain melakukan wawancara, observasi dilakukan dengan menganalisa referensi karya komparator dari media sejenis untuk mencari bagaimana penyusunan yang tepat untuk tema mengenai kesehatan. Adapun metode penelitian diambil melalui referensi literatur, jurnal, artikel online dan data-data lain yang berkaitan dengan tema dan konsep perancangan yang diangkat.

\section{HASIL DAN PEMBAHASAN}

\section{Target Audience}

Target atau sasaran dari perancangan komik strip tentang cara menjaga kesehatan mata di masa pembelajaran daring adalah pelajar berusia 9-16 tahun. Selain pertumbuhan tubuh, mata juga mengalami perkembangan, sehingga memungkinkan timbulnya masalah penglihatan. Selain itu, target dari perancangan ini adalah pelajar yang ingin mendapatkan informasi dan edukasi yang mengenai cara menjaga kesehatan mata di masa pembelajaran daring secara praktis, mudah dipahami sekaligus menghibur. Kemudian, target juga merupakan seorang yang aktif menggunakan media sosial Instagram dan suka membaca komik strip.

\section{Penyajian Media}

Seluruh media dari perancangan ini disajikan secara digital. Media utama yang digunakan untuk perancangan ini adalah komik strip yang dipublikasikan di media sosial Instagram dengan akun@komik_ceritamatakita. Komik strip terdiri atas 15-chapter yang setiap chapternya akan diunggah dalam bentuk multipost yang terdiri atas 6 post, yaitu sebuah cover komik, gambar per panel (4 post), dan sebuah gambar gabungan. Komik strip akan dibuat dalam ukuran 1080x1080 pixel fullcolor dan resolusi 300 dpi. Teknik pembuatan media yang digunakan juga teknik 
manual dan digital, mulai dari pembuatan sketsa yang beberapa dibuat secara manual dan digital, lalu pembuatan outlining, coloring dan editing yang seluruhnya dibuat secara digital.

\section{Konsep Perancangan}

Komik strip dirancang dengan tema mengenai kesehatan mata pelajar di masa pembelajaran daring. Inti dari cerita adalah menceritakan keseharian para tokoh selama masa pembelajaran daring, apa yang terjadi pada kesehatan mata para tokoh dan apa saja penyebab dan kebiasaan yang mempengaruhinya serta bagaimana cara mengatasi masalah tersebut. Konsep tersebut akan dikemas dalam bentuk cerita yang menghibur dan informatif.

Jenis ilustrasi yang digunakan adalah jenis kartun/ilustrasi anak-anak. Teknik yang digunakan dalam pembuatan ilustrasi adalah teknik deformasi, yaitu dengan menggunakan bentuk-bentuk dasar sebagai dasar dari obyek yang digambar. Perancangan ini menggunakan dua warna utama, yaitu warna biru dan warna kuning. Warna biru menggambarkan kejernihan, kebersihan, ketenangan, kesehatan, sedangkan warna kuning menggambarkan kecerdasan, semangat, keceriaan serta merupakan warna komplementer dari warna biru.

Gaya penulisan naskah berupa visualisasi dialog antar tokoh. Penulisan cerita didasarkan oleh keingintahuan tokoh mengenai masalah penglihatan serta berbagai nasihat dan saran mengenai cara menjaga kesehatan mata. Bahasa yang digunakan adalah bahasa Indonesia yana tidak formal namun tetap sopan karena menyesuaikan target dari perancangan yaitu pelajar berusia 9-16 tahun. Font utama yang digunakan dalam perancangan ini adalah Paytone One sebagai headline dan Comic Sans MS sebagai isinya.

\section{Judul Perancangan}

Judul dari perancangan komik strip tentang cara menjaga kesehatan mata di masa pembelajaran daring bagi pelajar usia 9 - 16 tahun adalah "Cerita Mata Kita". "Cerita" adalah suatu tuturan mengenai bagaimana terjadinya suatu peristiwa, "Mata" adalah organ penglihatan, "Kita" adalah target dari perancangan yaitu pelajar berusia 9-16 tahun. Cerita Mata Kita secara keseluruhan dapat 
diartikan sebagai cerita mengenai kesehatan mata pelajar berusia 9-16 tahun. "Cerita Mata Kita" juga memiliki akhiran "-ta" yang berirama sehingga membuat judul semakin unik, enak dibaca dan didengar serta mudah diingat.

\section{Logo}

Berikut adalah logo dari Cerita Mata Kita. Secara keseluruhan logo diatas telah mewakili inti dari perancangan ini. Mata berwarna biru melambangkan mata yang sehat, obyek lup menggambarkan kefokusan, dan warna kuning melambangkan sifat dari target perancangan, yaitu pelajar berusia 9-16 tahun. Warna biru dan kuning juga dapat merepresentasikan karakter di dalam komik strip (Kornel= biru, Lena $=$ Kuning).

\section{( Cerita Mata rita \\ Gambar 1. Logo Cerita Mata Kita \\ Sumber: Dokumentasi Penulis}

\section{Sinopsis}

Cerita Mata Kita mengisahkan mengenai keseharian seorang pelajar SD bernama Kornel dan kakaknya yang juga seorang pelajar SMA bernama Lena selama masa pembelajaran daring. Sepanjang cerita, Kornel dan Lena akan mengalami ketidaknyamanan pada mata mereka dan dengan bantuan dari orangtua dan dokter mata, Kornel dan Lena memahami pentingnya menjaga kesehatan mata dan memahami cara menjaga kesehatan mata mereka selama masa pembelajaran daring.

\section{Bagian Isi}

\section{A. Komik Strip}

Komik strip untuk perancangan ini berupa sebuah gambar digital dengan empat panel yang berukuran sama. Setiap panelnya akan diisi dengan ilustrasi dan dialog. Dialog pada komik strip menggunakan typeface Comic San MS Setiap cerita dalam komik strip akan dimulai dengan pembukaan, isi berupa informasi mengenai kesehatan mata dan diakhiri dengan sedikit humor. 


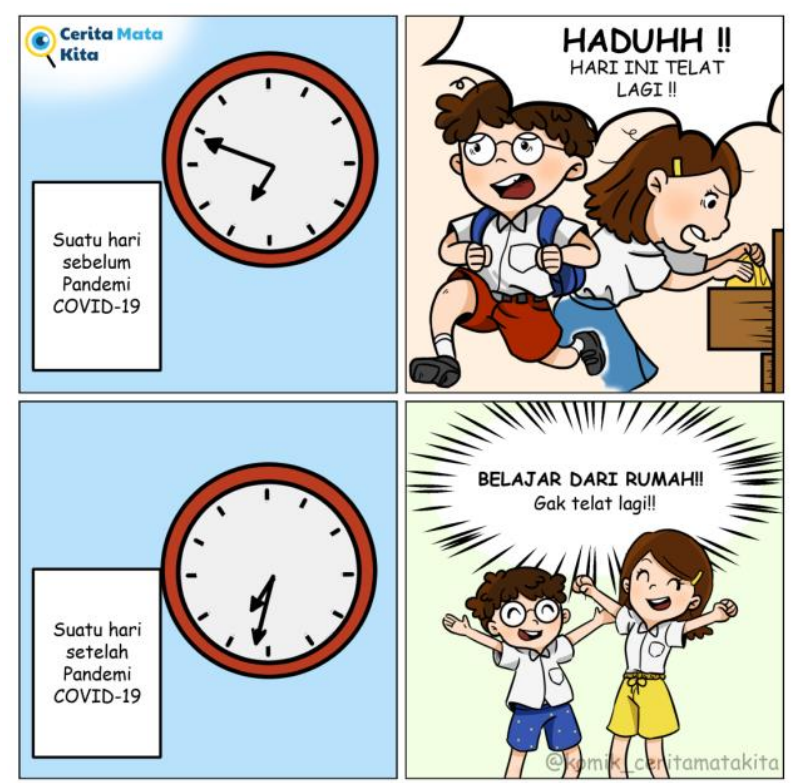

Gambar 2. Chapter

Sumber: Dokumentasi Penulis

\section{B. Preview Media Utama}

Berikut preview chapter 1 komik strip Cerita Mata Kita.
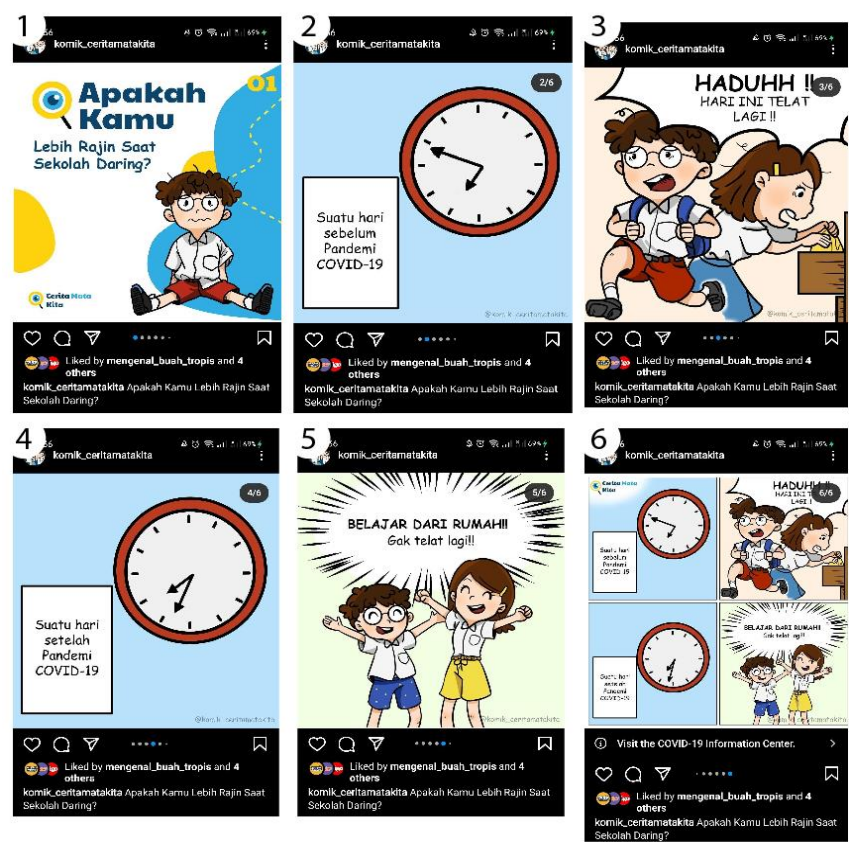

Gambar 3. Preview Chapter 1

Sumber: Dokumentasi Penulis 


\section{Media Pendukung}

Media pendukung digunakan untuk mempromosikan media utama komik strip Cerita Mata Kita.

1. Story Instagram

Story Instagram merupakan media dan konten pendukung dengan memanfaatkan fitur milik Instagram. Tujuan dari story Instagram adalah untuk memperkenalkan komik strip Cerita Mata Kita. Story Coming Soon adalah story sebagai teaser dari Cerita Mata Kita sedangkan story Kenalan Yuk untuk memperkenalkan tokoh Cerita Mata Kita.

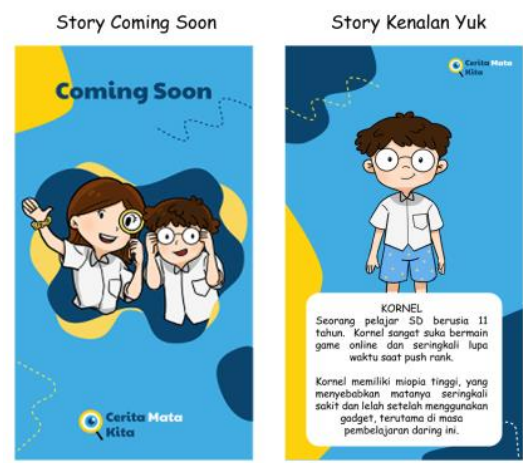

Gambar 4. Story Instagram

Sumber: Dokumentasi Penulis

\section{Digital Poster}

Digital poster adalah tiga post Instagram bersambung sebagai teaser dari komik strip Cerita Mata Kita.

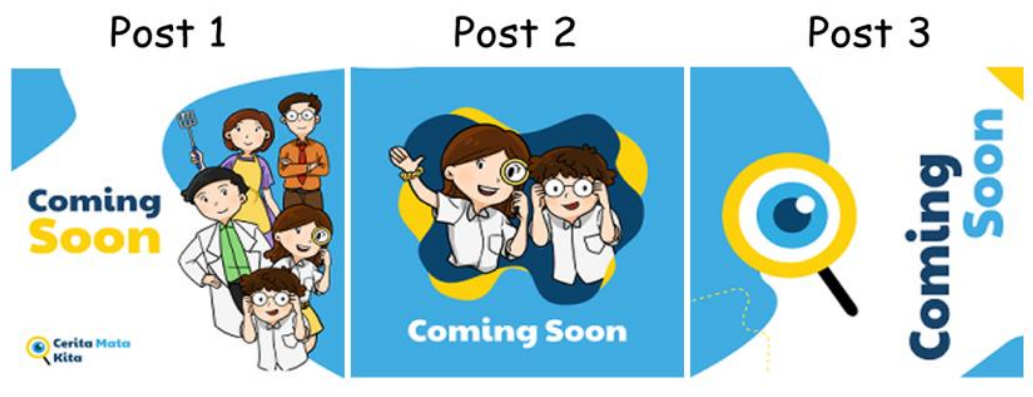

Gambar 5 Digital Poster

Sumber: Dokumentasi Penulis 


\section{Stiker Whatsapp}

Koleksi stiker Whatsapp bertemakan Cerita Mata Kita. Stiker Whatsapp dapat diperoleh melalui link linktr.ee/ceritamatakita21 yang terdapat di bio Instagram @komik_ceritamatakita.

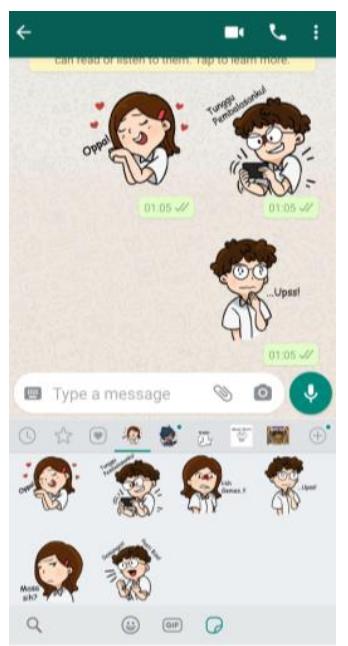

Gambar 6. Stiker Whatsapp

Sumber: Dokumentasi Penulis

4. Masker kain

Perlengkapan untuk digunakan di masa pandemic COVID-19. Masker kain dapat diperoleh melalui giveaway dan minigames.

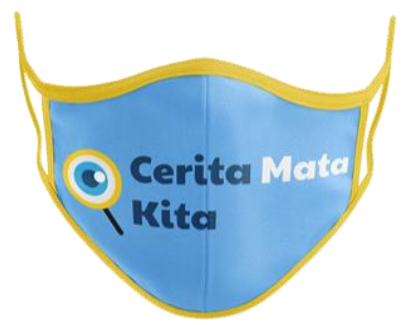

\section{Gambar 7 Masker Kain}

Sumber: Dokumentasi Penulis

\section{Sleep Mask}

Perlengkapan yang digunakan agar kualitas tidur menjadi lebih baik dan terhindar dari penggunaan gadget sebelum tidur. Sleep mask dapat diperoleh melalui give away dan mini games. 


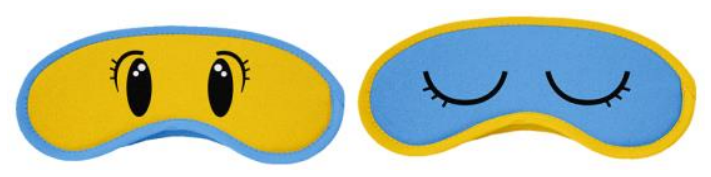

Gambar 8 Sleep Mask

Sumber: Dokumentasi Penulis

\section{Glasses case}

Wadah untuk menyimpan kacamata. Glasses case dapat diperoleh melalui give away dan mini games.

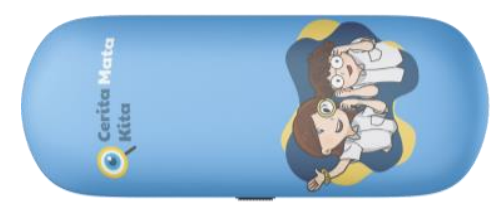

Gambar 9 Glasses Case

Sumber: Dokumentasi Penulis

\section{Pouch}

Wadah untuk menyimpan peralatan seperti glasses case dan masker kain.

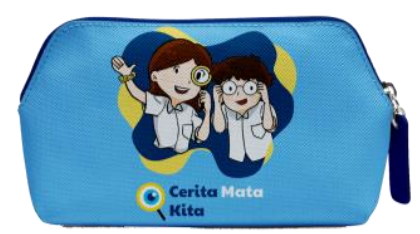

\section{Gambar 10 Pouch}

Sumber: Dokumentasi Penulis

\section{Tote Bag}

Tas kanvas yang digunakan untuk membawa pouch, glasses case dan masker kain. Tote bag dapat diperoleh melalui giveaway dan minigames,

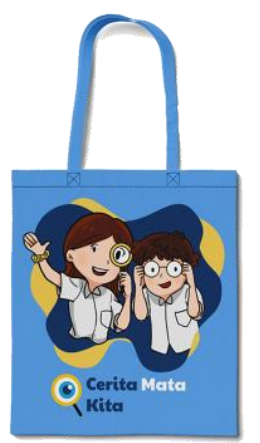

Gambar 11 Tote Bag

Sumber: Dokumentasi Penulis 
9. Kaos

Pakaian bertemakan Cerita Mata Kita. Kaos dapat diperoleh melalui giveaway dan minigames.

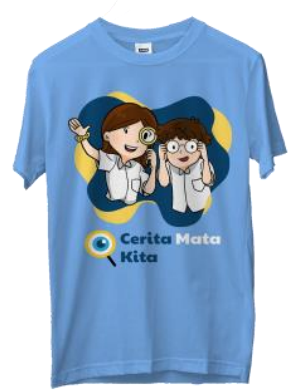

Gambar 12 Kaos

Sumber: Dokumentasi Penulis

10. Phone Case

Pelindung smartphone bertemakan Cerita Mata Kita. Phone case dapat diperoleh melalui giveaway dan minigames.

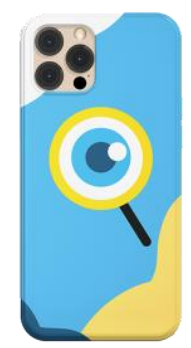

\section{Gambar 13 Phone}

Sumber: Dokumentasi Penulis

\section{SIMPULAN DAN SARAN}

\section{Simpulan}

Masalah kesehatan mata pelajar di masa pembelajaran daring merupakan topik yang penting untuk dibahas saat ini. Selama masa pembelajaran daring ini, pelajar menggunakan gadget dalam waktu yang cukup lama, ditambah lagi dengan aktivitas lain yang juga berbasis daring dan kurangnya aktivitas di luar ruangan. Hal ini dapat menyebabkan memicu munculnya masalah penglihatan pada pelajar usia 9-16 tahun yang sedang dalam masa pubertas, terutama pelajar dengan factor turunan miopia dari orangtuanya. Pelajar perlu mengetahui cara-cara untuk 
menjaga kesehatan matanya dengan memberikan informasi dan edukasi yang tepat dan mudah dipahami. Komik strip adalah salah satu konten visual di media sosial Instagram yang mampu untuk membawakan informasi dan edukasi dengan praktis dan mudah dipahami sekaligus menghibur.

Oleh karena itu, melalui perancangan ini menghasilkan sebuah serial komik strip berjudul "Cerita Mata Kita". Komik strip Cerita Mata Kita ini dipublikasikan di akun media sosial Instagram @ komik_ceritamatakita. Perancangan komik strip ini juga didukung oleh konten pendukung seperti minigames, funfacts, twibbon dan giveaway, dan media pendukung berupa media digital seperti story Instagram, digital poster, stiker Whatsapp dan merchandise.

\section{Saran}

Diharapkan melalui perancangan ini, pelajar usia 9-16 tahun sadar akan pentingnya menjaga kesehatan mata di masa pembelajaran, terutama di masa pandemic COVID-19. Sampai terselesaikannya perancangan ini, Pandemi COVID19 masih berlangsung, begitu juga dengan sistem pembelajaran daring. Oleh karena itu, pembaca dapat memperluas topik dari perancangan ini, baik mengenai kesehatan mata maupun mengenai kesehatan lainnya. Topik lain berkaitan yang dapat diangkat adalah mengenai menjaga postur tubuh selama masa pembelajaran daring, mengenai kesehatan mental, mengenai tips menjaga motivasi selama masa pembelajaran daring dan amsih banyak lagi. Pembaca juga dapat memperluas media dari perancangan ini, yaitu dengan buku ilustrasi, animasi, audio book dan masih banyak lagi.

\section{DAFTAR PUSTAKA}

Agung. (2020, 05 Mei) Mencegah Myopia Booming di Tengah Pandemi Covid-19. Diakses dari ugm.ac.id pada 8 April 2021 pukul 13.44 WIB. https://www.ugm.ac.id/id/berita/19386-mencegah-myopia-booming-ditengah-pandemi-covid-19

Azzura, F. (2019). Perkembangan Komik Strip di Era Media Sosial Tahun 2005 2015. Jurnal Pendidikan Seni Rupa, 8(1) - p, 62-71. Diakses dari http://journal.student.uny.ac.id/ojs/index.php/serupa/article/view/14853

CENTERS FOR DISEASE CONTROL AND PREVENTION. (Nd). Child Development: Middle Childhood (9-11 Years). Diakses dari cdc.gov pada 
26 Februari 2021 pukul 18:59 WIB.

https://www.cdc.gov/ncbddd/childdevelopment/facts.html

Chandler, K. (2015, 10 September). Literacy Milestones 9-10. Diakses dari kidspot.com.au pada 12 Februari 2021 pukul 19:00 WIB. https://www.kidspot.com.au/school/preschool/preschool-literacy/literacymilestones-910/news-story/386203381a6ba603ca6b6c463be33394\#

Chandra, J., \& Kartadinata, E. (2018). Hubungan antara durasi aktivitas membaca dengan astenopia pada mahasiswa. Jurnal Biomedika dan Kesehatan, 1(3), 185-190. https://jbiomedkes.org/index.php/jbk/article/view/40/30

Espinosa, H. (2014). The 5 Choices of Comics Theory and What It Has to do with You. Diakses dari ucreative pada 21 Agustus 2021 pukul 22:37 WIB. https://www.ucreative.com/articles/comicstheory1/

GreatSchools. (2010, 13 September). Child Development: 13 - To - 16-Year Olds. Diakses pada 26 Februari 2021 pukul 18:57 WIB. https://www.greatschools.org/gk/articles/child-development-13-to-16-yearolds/

Rsjakarta. (2021, 26 Maret). Mengenali Rabun Jauh (Miopia). Diakses dari rsjakarta.co.id pada 20 April 2021 pukul 14:37 WIB

The Impact of Myopia and High Myopia: Report of the Joint World Health Organization-Brien Holden Vision Institute Global Scientific Meeting on Myopia, University of New South Wales, Sydney, Australia, 16-18 March 2015. Geneva: World Health Organization; 2017. Licence: CC BY-NC-SA 3.0 IGO

Widiyana, E. (2020. 27 Juli). Waspada Kesehatan Mata Anak Selama Belajar Daring. Detiknews. Diakses dari news.detik.com pada 21 Oktober 2020 pukul 18:39 WIB. https://news.detik.com/berita-jawa-timur/d5109681/waspada-kesehatan-mata-anak-selama-belajar-daring

Widiyanto, D. (2020, 26 April) Hati-hati, Bahaya Belajar Sistem Daring Bagi Kesehatan Mata. KrJogja.com. Diakses dari www.krjogja.com pada 21 Oktober $2020 \quad$ pukul 18:21 https://www.krjogja.com/angkringan/gaya-hidup/kesehatan-danseksualitas/dr-suharjo-pak-octo/ 